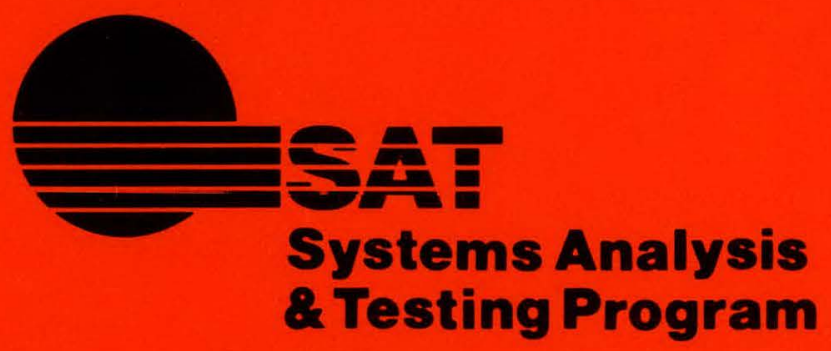

\title{
Applications and Systems Studies for Solar Industrial Process Heat
}

Kenneth C. Brown
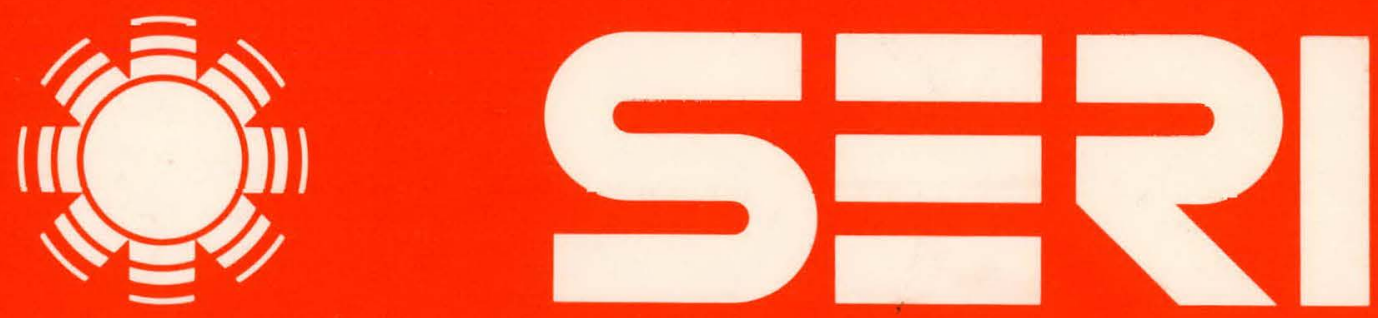

Solar Energy Research Institute

A Division of Midwest Research Institute

1536 Cole Boulevard

Golden, Colorado 80401

Operated for the

U.S. Department of Energy under Contract No. EG-77-C-01-4042

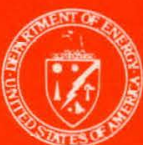




\section{DISCLAIMER}

This report was prepared as an account of work sponsored by an agency of the United States Government. Neither the United States Government nor any agency Thereof, nor any of their employees, makes any warranty, express or implied, or assumes any legal liability or responsibility for the accuracy, completeness, or usefulness of any information, apparatus, product, or process disclosed, or represents that its use would not infringe privately owned rights. Reference herein to any specific commercial product, process, or service by trade name, trademark, manufacturer, or otherwise does not necessarily constitute or imply its endorsement, recommendation, or favoring by the United States Government or any agency thereof. The views and opinions of authors expressed herein do not necessarily state or reflect those of the United States Government or any agency thereof. 


\section{DISCLAIMER}

Portions of this document may be illegible in electronic image products. Images are produced from the best available original document. 
Printed in the United States of America Available from:

National Technical Information Service

U.S. Department of Commerce

5285 Port Royal Road

Springficld, VA 22161

Price:

Microfiche $\$ 3.0^{\circ}$

Printed Copy $\$ 4.00-5,20$

\section{NOTICE}

This report was prepared as an account of work sponsored by the United States Government. Neither the United States nor the United States Department of Energy, nor any of their employees, nor any of their contractors, subcontractors, or their employees, makes any warranty, express or implied, or assumes any legal liability or responsibility for the accuracy, completeness or usefulness of any information, apparatus, product or process disclosed, or represents that its use would not infringe privately owned rights. 
APPLICATIONS AND SYSTEMS STUDIES FOR SOLAR INDUSTRIAL PROCESS HEAT

KENNETH C. BROWN

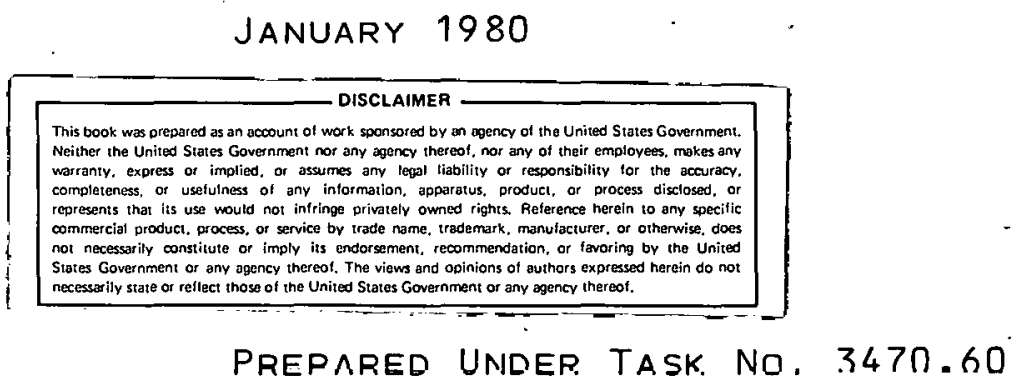

Solar Energy Research Institute

1536 Cole Boulevard Golden. Colorado 80401

A Division of Midwest Research Institute

Prepared for the U.S. Department of Energy

Contract No. EG $\cdot 77 \cdot \mathrm{C} \cdot 01 \cdot 4042$ 


\section{POREWORD}

Supported by Systems Development Division, Office of Solar Applications, DOE, this report summarizes the results of SERI work in systems analysis, economic analysis, and application studies for solar thermal industrial process heat. The report, performed under task numbers 3403,3424 , and 3473 , also describes research plans in applications and system studies for fiscal year 1980 and the general direction of application-oriented research at SERI in the future.

The dedication and excellence of SERI staff who have contributed to this program should be evident from the accomplishments of the applications and systems study program. We are indebted to D.W. Kearney, IPH Program Leader, for the effective management and personal style that has facilitated this work. We are particularly grateful to DOE's Agricultural and Industrial Process Heat Branch for the considerable freedom and consistent support that have made this program not only possible, but fruitful.

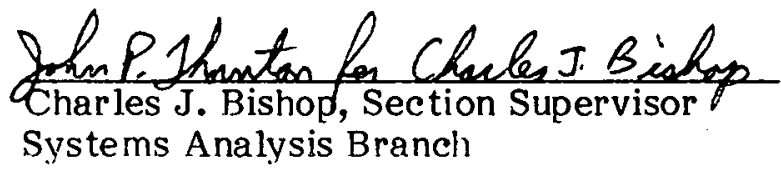

Approved for:

SOLAR ENERGY RESEARCH INSTITUTE

Neil H. Woodley, Branch Chief

Systems Analysis Branch 


\section{THIS PAGE}

\section{WAS INTENTIONALLY LEFT BLANK}




\section{SECTION 1.0}

\section{INTRODUCTION}

The effective use of alternative energy technology in industry will depend, to a large extent, on the successful recognition, development, and implementation of appropriate applications for alternative energy supply. Because solar energy competes with many other suitable, and perhaps more flexible, energy delivery systems, it is important that applications be chosen to maximize competitive advantages. This requires that issues of location, temperature needs, schedule, fuel price, fuel availability, and environmental constraints be fully explored to identify applications for solar energy. It also necessitates that system design and engineering initially satisfy the requirements of the most appropriate applications and that systems development continue to respond to market needs as these needs develop. This communication between market needs and technology research and development has been the traditional purview of the systems analyst. Where emphasis in a program is on the effective introduction of a technology in an application, as in the introduction of solar energy to industry, the program must be heavily motivated by market needs as interpreted by system and application analysis.

The Solar Energy Research Institute (SERI) initiated efforts in applications and systems studies for solar industrial process heat (IPH) in early 1978. Since that time, the program has produced key findings regarding the industrial marketplace, has analyzed and evaluated numerous solar IPH. system configurations, and is extensively expanding its applied research in application identification, model development, and system design. These studies are a key element of the diversified solar industrial program at SERI and are fundamental to a unified approach toward solar application to industrial energy needs.

This report highlights some of the more important aspects of the industrial systems and applications study program. The work completed during fiscal years 1978 and 1979 is reviewed and the program of study for fiscal year 1980 is presented. In addition, the report concludes with a summary of issues that should be addressed by the Institute in future years.

\section{SECTION 2.0}

\section{8-1979 PROGRAM SUMMARY}

Systems analysis activity during fiscal years 1978 and 1979 was carried out in two major SERI tasks. Effort during 1978 was directed toward the creation of methodologies and data which could be used to identify national markets for solar industrial process heat systems. This work was extended and diversified in 1979 under a separate task designation. This task was a combination of efforts in related areas, continuing certain aspects of work initiated in 1978 and embarking upon studies in other fields. Five areas of study were emphasized, as described here. 


\subsection{APPLICATIONS ANALYSIS}

During 1979 work was completed on a major project initiated in 1978 known as "industrial process end-use matching." The methodology which was developed in this project provides a means of analyzing the relative merit and feasibility of industrial process and solar system combinations in a variety of geographical locations. The results of such analyses determine advantageous near-term solar IPH applications. The codes and data bases (shown in Fig. 2-1) provide not only the automation required for a large-scale feasibility analysis, but also the flexibility necessary for various scnsitivity and case studies in particular locations and for specific industrial processes [1].

During 1978 it became increasingly clear that the lack of specific and extensive data on industrial process heat demand in many U.S. cities limits the effective national application of end-use matching. However, the codes which were developed (PROSYS/ ECONMAT) are extremely useful in smaller-scale studies when ample data is available. PROSYS (for PROCESS HEAT SYSTEMS MODEL) is a solar thermal system performance valuation code. The code uses the input specifications of a given industrial process (such as required temperature, heat rate, and heating mechanism) to model solar IPII systems in a range of sizes for all appropriate collector types. The average annual system energy output is calculated using the method of Rabl and Collares-Pereira [2] for the given location and system size. ECONMAT (for ECONOMIC ANALYSIS AND MATCHING) uses output from PROSYS to calculate total system costs for the given location and to calculate the life-cycle costs of the system in the given application. The economic analysis provides either net present value, payback, or levelized cost of the solar system as a measure of cost-effectiveness and then lists the system and industry combinations which are most attractive in each location.

To obtain the detailed process data required by PROSYS/ECONMAT, an in-depth analysis of several industries was undertaken in 1979 to supplement publislied energy use data with actual data obtained during site visits. Industries for this analysis were chosen on the basis of near-term potential for solar IPH. Site visits were made to fluid milk dairies, bakeries, paint manufacturers, nonferrous fnundries, and wet corn inilliug plants. In additlon, detailed process information was collected on the petroleum refining industry, providing more thorough estimates of typical refinery heating loads and plant characteristics [3]. The ability of solar IPH systems to satisfy actual and typical loads was then determined for all 26 SOLMET sites. [SOLMET and SOLDAY are the solar resource data sources that have been adopted as standards for all Department of Energy (DOE) analyses. The data is based on rehabilitated 20-year records from the National Weather Service and is available for 26 cities in the United States.] The results were mapped to indicate application suitability for immediate and future installations [4].

In the preceding analysis process, a number of improvements in PROSYS/ECONMAT wcrc implemented. For example, shading loss and heat extraction efficiency factors were adder to impiove the accuracy ol the performance code PROSYS. The economic routines in ECONMAT were revised to provide both a ranking based on unit capital capacity cost [\$/(MBtu/yr)] and an optional net present value analysis. More recently, several options for the calculation of payback or break-even fuel price were added. These improvements, together with graphic output capability (as seen in Fig. 2-2) augmcnt the effectiveness of the codes for sensitivity analysis and case studies. The development of PROSYS/ECONMAT will continue in 1980, culminating in the publication of a user's manual and code documentation during the summer of 1980. 


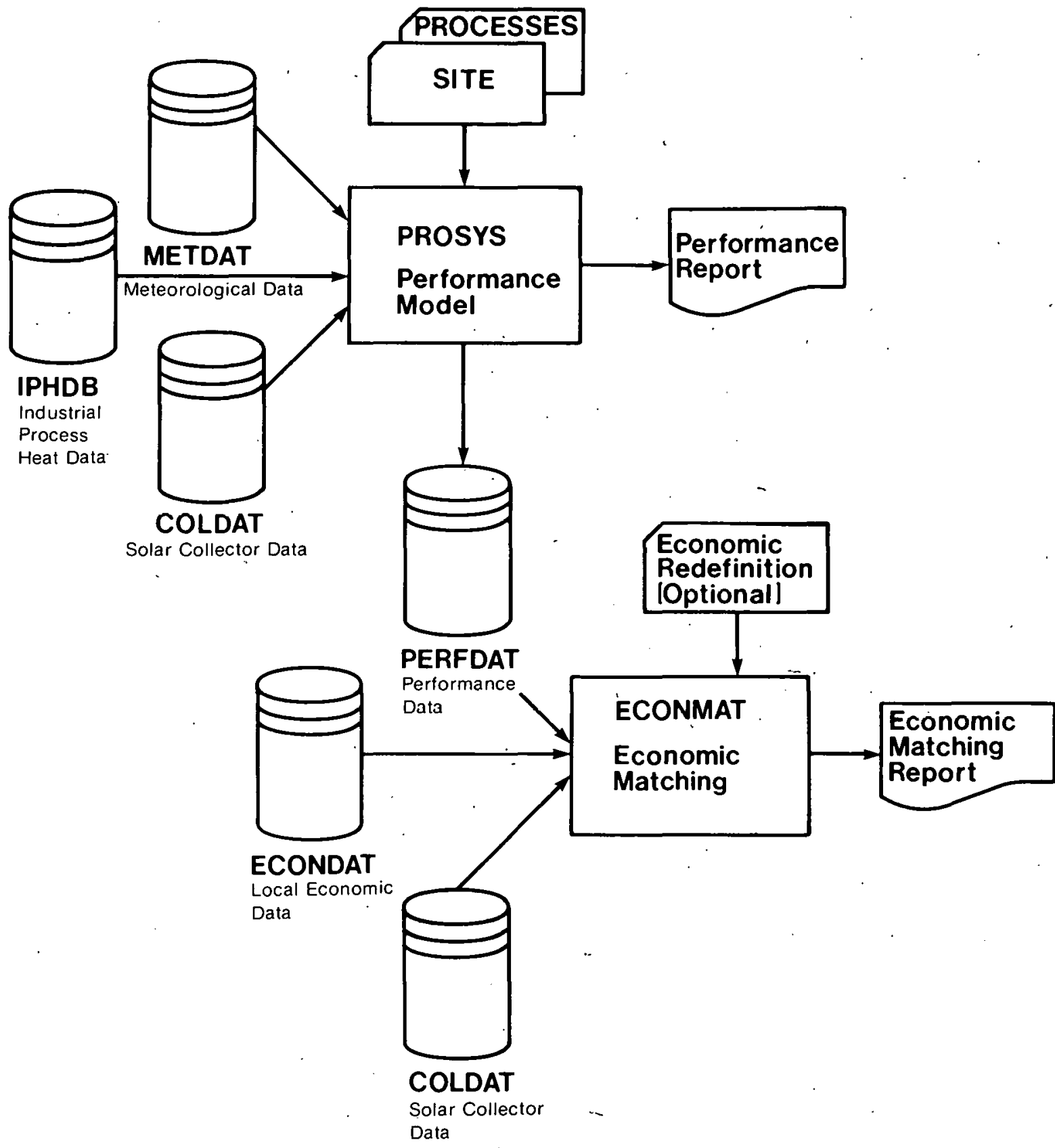

Figure 2-1. System Diagram for the Applications Analysis Methodology known as PROSYS/ECONOMAT 


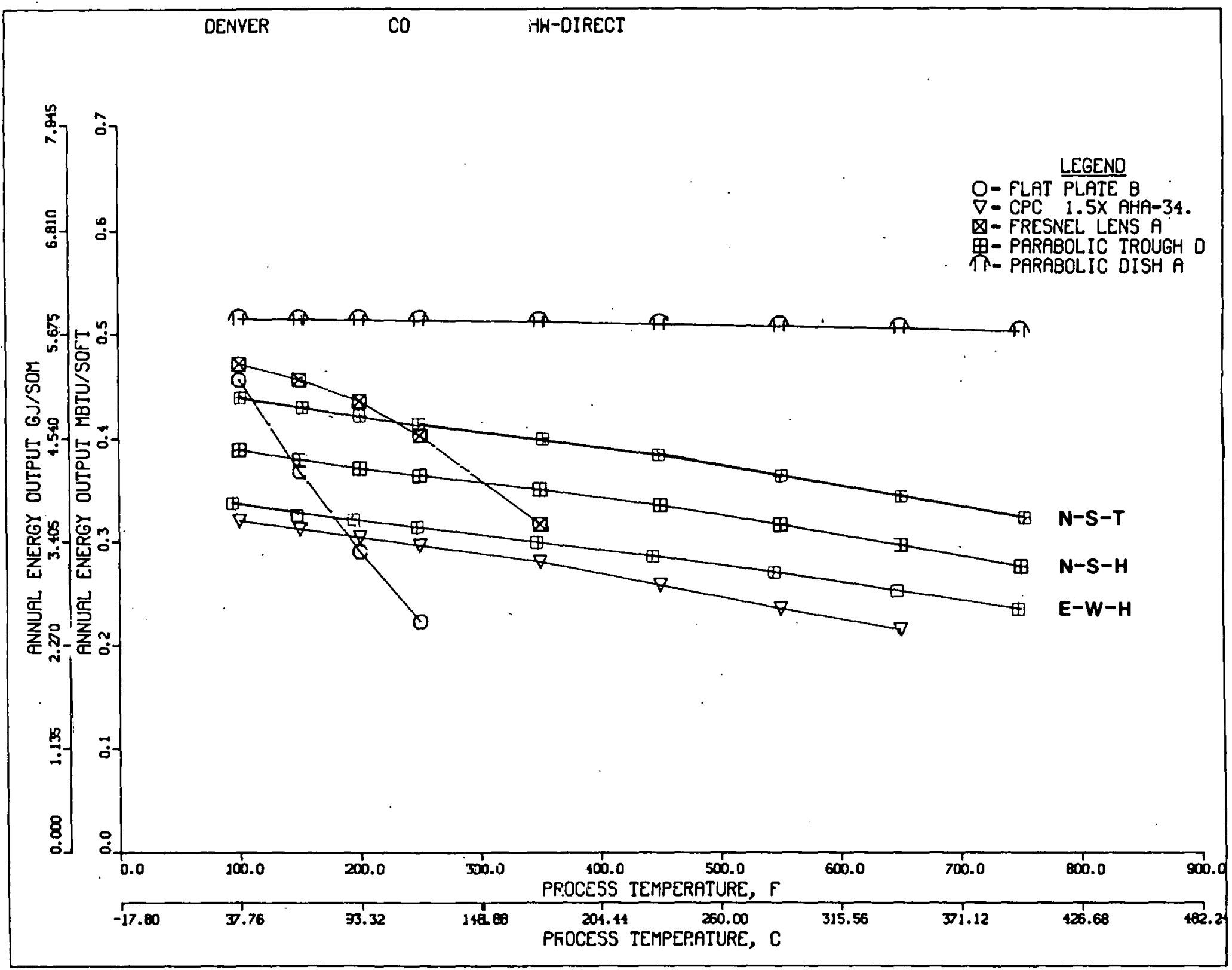

Figure 2-2. An Example of the Graphics Capability of PROSYS/ECONOMAT 


\subsection{CASE STUDIES}

Specific data on industrial energy use is necessary as a check on the results of computerized end-use matching. The importance of this specific data spurred the creation of the highly successful industrial case-study program in 1978. Following two successful industrial case studies in luggage manufacturing and commercial laundering, six more detailed studies were concluded in 1979 and another two studies were initiated. The purpose of the industrial case studies is to give SERI staff the opportunity to encounter design issues typical of actual IPH installations, including those of limited land availability, unusual operating schedules, conservation opportunities, and process reconfiguration. At the same time, SERI assists plant engineers interested in an initial assessment of solar suitability to their facility.

A case study is initiated with a plant visit and energy audit. The energy audit often involves numerous iterations with plant personnel to resolve data discrepancies; therefore, a single plant may be visited several times. New measurements often are required. After the plant energy balance is determined, suitable processes for solar application are identified. Solar collector systems are sized for the process, evaluated; and then assigned a cost using PROSYS/ECONMAT. The viability of an investment in the solar IPH system is determined using the specific financial criteria supplied by the plant manager. Investment opportunity is evaluated on the basis of net present value, which is conveniently summarized with respect to various competing fuel prices as shown in Fig. 2-3. The analysis of conservation opportunities is one of the most important aspects of a case study. In many of the studies completed in 1979, conservation opportunities offered greater economic returns than the installation of a solar IPH system, while in certain cases, the implementation of energy conservation measures in concert with solar system installation offered the most attractive returns.

Industries investigated in the case-study program include paint resin manufacturing, meatpacking, baking, dairies, metal container manufacturing, oil recovery, and corn milling. Future studies will include, among others, the flexible packaging industry and potassium chloride purification [5].

\subsection{FIELD PROJECT DATA ANALYSIS}

Uniform collection and analysis of operating and cost data from IPH field experiments is an important aspect of the Department of Energy's (DOE) IPH Field Engineering Test Program. Accordingly, at the request of DOE, SERI collected performance and cost data on the six operating IPH field tests (three hot water projects and three hot air projects) and reported on the comparative performance, cost, and operating experiences of the six projects in their first year of operation. In addition, SERI provided guidelines for data acquisition in future projects, including the preliminary specification of a uniform data acquisition system (DAS).

Existing DAS and data categories used by the six operating IPH field tests and the proposed low-temperature steam projects were compared to a set of data specifications compiled by resource, materials, and engineering specialists at SERI. Discussion with IPH contractors and with DAS equipment suppliers were held to specify reasonable guidelines for DAS hardware and data categories. These guidelines were presented to contractors in the SPIPS Program (Solar Production of Industrial Process Steam), which is one of several engineering field test and demonstration programs sponsored by the Office of Solar Applications, DOE. Cost and economic standards were introduced in a separate effort coordinated with this subtask (see Sec. 2.5). 


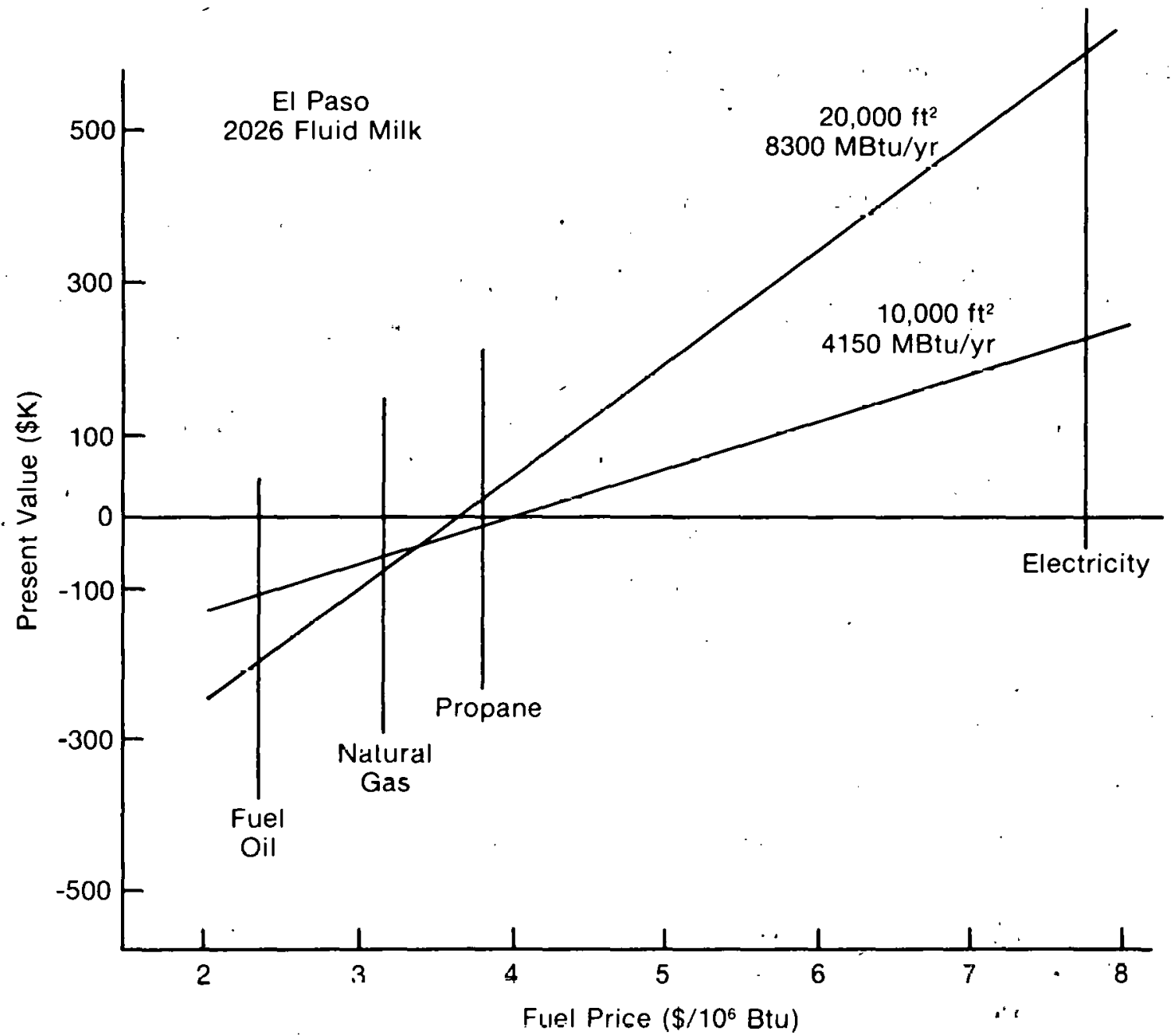

Figure 2-3. Net Present Value Analysis Typical of IPH Case Studies 
Visits to the six operating IPH field tests were made in 1979.* The data gathered was analyzed, compared, and summarized by SERI. In general, it was apparent that although solar system availability was good, use of the solar system was significantly lower than expected, thus reducing effective annual energy delivery. In addition, thermal leakage and parasitic power requirements tended to reduce net system efficiency. As a result, net annual system efficiency in many IPH projects was less than half of that predicted. Certain system design improvements and common problems were identified in the study. This important effort will continue in FY80 under a separate task designation [6].

\subsection{COMMUNICATIONS}

One goal of the systems and applications study program is to support technology commercialization through information dissemination and communications. The SERI Communications Branch analyzed the most immediate needs of the IPH Program during 1979 and formulated a plan for increasing the exposure of prospective solar users in industry to research and analysis advances at SERI. One result of the 1979 communications program was publication of the brochure Putting the Sun to Work in Industry, [7] first introduced at the Six th Energy Technology Conference in Washington, D.C., in Feb. 1979. The pamphlet has proven extremely successful, with well over 9,000 copies distributed since the first printing. The success of this effort, as well as the encouraging response to features concerning IPH in SERI's monthly In-Review, are crucial to the success of SERI industrial programs and will be supported in 1980 .

In addition to projects in the SERI Communications Branch, media relations and audiovisual presentations were coordinated with the SERI Public Information Office (PIO). In particular, PIO helped to prepare a 15-minute color slide program and script on solar IPH for case-study and site-visit teams. The slide program was warmly received by industrial audiences and has since been requested by several Regional Solar Centers for their activities.

\subsection{GENERAL SUPPORT}

Formal task activities reflect only a part of the effort in applications and system study for solar IPH. Several major nontask activities deserve special mention:

- Standard Economic Analysis - The 1978 Solar IPH Conference requested a standard means of cost reporting and economic analysis for contractors, users, analysts, and government officials. SERI, in cooperation with Lawrence Livermore Laboratory in Livermore, Calif., developed such a procedure manual [8] .

- Industrial Energy Data Collection - At the suggestion of McDonnell-Douglas Astronautics Co., SERI volunteered to rhair a meeting of DOE laboratories and contractors interested in industrial energy-use data collection. Held in Los Angeles on 28-29 Nov. 1978, this meeting resulted in an informal agreement among 20 laboratories and contractors to share data gathered on plant visits and interviews and to assemble this data at SERI in a standard format for

*These projects include: Campbell Soup, Sacramento, Calif.; L\&P Foods, Fresno, Calif.; LaCour Kiln Service, Canton, Miss.; Gold Kist Foods, Decatur, Ala.; Riegel Textiles, LaFrance, N.C.; York Building Products, Harrisburg, Pa. 
cooperating organizations. At present, SERI has compiled a list of 152 industrial interview contacts [9].

- Solar Production of Industrial Process Steam (SPIPS) - At the request of DOE's San Francisco Operations Office, SERI hosted the Conceptual Design Review for seven high-temperature steam project contractors on 23-25 Jan. 1979. Subsequently, two SERI staff members were named to the SPIPS Technical Advisory Board.

- Program Planning Support - Task personnel throughout the year supported program planning and review at DOE. For example, a Commercialization Readiness statement was prepared for the IPH Resource Manager in connection with the National Plan for Accelerated Commercialization (NPAC). Staff members also upheld the SERI Technology Commercialization Division in the review uf NPAC planning and presented $a$ briefing to the NPAC Steering Committee on $5 \mathrm{Apr}$. 1979. 3ERl euuldluted the preparation of an ovcrvicw briefing un sulul IPH for the office of Encrgy Tcchnology and sublillled a summary of major issues in support of IPH program planning for DOE.

- Regional Center Support - Through involvement in NPAC, SERI led in advising Regional Centers on appropriate activity in solar IPH and in helping to coordinate regional efforts. SERI was invited to serve on the Source Evaluation Board for the Mid-America Solar Energy Complex solicitation on industrial applications identification. In addition, staff members helped to organize and contribute to a meeting of regional representatives on 26 Sept. 1979 to informally discuss cooperative programs in solar IPH.

\section{SECTION 3.0}

\section{PROGRAM}

Resiources for the 1980 applications and systems study program for solar IPH are approximately three times as great as for 1979, allowing an expanded and more vigorous program in this important area of -research. Successful programs such as the industrial case studies will be more heavily supported in 1980 than in the past, while important ncw fields of research in generic systems, industrial parks, and systcm cost analysis will be initiuled. The FY 80 program will concentrate on the five key areas described in this sertinn,

\subsection{PERFORMANCE MODELS}

The computer codes PROSYS/ECONMAT developed by. SERI to evaluate solar IPH applications have been used extensively in applications analysis, parametric sensitivity studies, and case studies. It is anticipated that the software will be heavily employed in several new SERI studies. Because of the continued use of the software and its significant role in diverse studies, it is important to maintain a high level of accuracy in the model. Thus, the model will be reviewed and improved, and the data bases appropriately expanded. To extend the use of the software, a user's manual will be prepared. Regional centers are interested in the PROSYS/ECONMAT software for use in analyses of local solar industrial potential. A package containing a user's manual, codes, and data bases 
can be distributed to the regional centers to assist these efforts. A method for evaluating and validating PROSYS/ECONMAT and other IPH codes (SOLSYS, SOLTES, etc.) should be proposed if reliability in performance models is to be sustained. Therefore, support will be given to model validation efforts coordinated by the inter-laboratory Systems Simulation and Economic Analysis working group. Tests of PROSYS/ECONMAT will be conducted according to the standards developed by this group.

\subsection{GENERIC SYSTEMS}

As a logical extension of the applications analyses performed using PROSYS/ECONMAT during 1978 and 1979 , a closely related area of research will be initiated in 1980 . A feasibility analysis of the concept of standardized or "generic" solar systems will be performed under subcontract to SERI, based upon the premise that more competitive solar IPH systems might be designed as package entities (collector, transport, storage, control) for standard classes of duty (such as hot water $120^{\circ} \mathrm{F}-200^{\circ} \mathrm{F}$ ). Such systems could be designed, installed, and sold much like conventional boiler equipment and thus benefit from equipment standardization and performance optimization. From past experience with actual IPH studies, one can select one or two generic load categories that are applicable to a large number of industries. The advisability and feasibility of the "generic system" will be analyzed with respect to both technical and marketing issues.

\subsection{INDUSTRIAL CASE STUDIES}

The highly successful industrial case study program will expand in FY80. Several more case studies will be completed during the year. These case studies provide insight into the opportunities for and constraints on solar energy in actual industrial plants; also, they advertise IPH to potential users and yield a realistic comparison of solar and conservation alternatives for industry. Attention will be focused on designing and recommending integrated systems concepts that will incorporate process reconfiguration and conservation measures while illustrating the implementation of solar energy.

\subsection{COST ANALYSIS}

The fourth major effort supports the Technology Characterization Task of the SERI Planning, Analysis, and Social Science Program. The objective of the Technology Characterization Task is to assign typical cost and performance estimates to all solar technologies in order to provide DOE decision makers with a consistent comparative data base on energy technologies. The solar process heat program greatly needs a thorough analysis of current and expected system costs. Fortunately, the program benefits from cost information from field experiments as well as from research and design reports. Cost information will be gathered in a standard format from the completed IPH engineering field experiments ( 10 projects). This data, together with other information, will be analyzed to elucidate the current state of solar IPH costs and the near-term potential for design cost reduction. In addition, cost analysis will yield information on realistic expectations for future system cost reduction and guidance on design modifications. Cost analysis reports in this subtask will support both the Technology Characterization Task and the IPH Field Test Monitoring Task. 


\subsection{IPH SYSTEMS IN INDUSTRIAL PARKS}

Since the concept of the industrial park evolved in Great Britain 83 years ago, a large portion of new industrial development has been funneled into areas dedicated to industrial use and characterized by large landscaped areas surrounding low-rise structures.* To meet national goals for displacement of nonrenewable industrial fuels (2.6 quads by the year 2000) one must consider the role of solar energy in tomorrow's industry, not just today's. Industrial park development will probably continue to be common throughout the remainder of this century; therefore, it is crucial that the application of solar energy to plants within industrial parks be investigated.

Industrial park applications for solar energy appear to offer several advantages. For instance, land availability, particularly in developments that will employ solar energy, should be less constraining. Load demand among several plants may have a more uniform distribution and allow for greater solar. system use than in a single plant. Process reconfiguration in the initial planning of an industrial park may enhance solar viability as might the economics of larger scale systems. Finally, it may be possible to cooperatively institute unique, lower cost financing arrangements.

This subtask will locate U.S. industrial parks and investigate development trends. Industrial park energy use will be determined, and typical de mand profiles and appropriate solar design possibilities will be characterized. Solar energy will be viewed from the perspective of an integrated solution to future energy problems; i.e., the use of solar IPH, solar cogeneration, solar electric power, or solar space heating sytems will be analyzed and compared to select the most appropriate configuration and combination of alternatives. Process redesign and conservation will be incorporated. The entire spectrum of solar technologies will be considered to select the appropriate use of the solar resource. Although the preanalysis will focus on general issues, two specific industrial parks will be selected for a detailed and practical analysis of these concepts. The actual cases, as in the IPH case studies, provide a necessary test of general hypotheses and contributed to the Institute's credibility with the industrial user.

\section{SECIION 4.0}

\section{FUTUUTE PLANS}

The applications and systems study program introduces two important new concepts. First, it is clear that the national program in solar energy must turn toward future patterns of energy use, instead of focusing on various versions of the present scenario. This will be especially important in the industrial sector. For example, one very promising application of solar IPH identified in several past studies is the supply of heat at approximately $190^{\circ} \mathrm{F}$ to electroplating baths. Recent advances in chemical electroplating technology, such as cold chemical plating, may make heated electroplating baths obsolete and thereby eliminate the potential for solar substitution in this market. However, energy availability problems in wet corn milling operations have caused plant personnel to seriously consider reduced throughput rates and lower temperature operation to

*In 1978 alone, over $\$ 4$ billion was invested in new plant construction and expansion in the southeastern United States, representing over 40 new plant starts, many of them within industrial park areas. 
accommodate either solar energy or cascaded energy streams. SERI's investigation of solar potential in new industrial plant construction (as proposed in the industrial parks study) is a first step in preparing solar energy for tomorrow's markets.

The second concept is an overall approach to industrial energy use. An industrial engineer is not interested in programmatic boundaries or technologically biased analyses. Responsible for efficient and reliable production, he wants only the best solution to his energy problem. Solar studies should identify the optimal combination of systems and technologies for a specific job and, hence, should be considered "industrial energy systems studies" and not simply "TPH studies" or "solar thermal IPH studies." As proposed in the industrial parks study, SERI will select from an array of solar technologies and system configurations to meet industrial plant needs. Attention will also be given in each study to process reconfiguration, conservation, and to interactions between solar supply and conventional energy systems.

These two concepts epitomize the direction of future SERI programs in systems analysis for industrial solar energy. Specifically, SERI has emphasized the following areas in its Institutional Plan:

- Assemble a comprehensive guide to industrial solar energy systems that distills the experience in integrated system design for the benefit of plant engineers interested in an assessment of solar energy for their facility.

- Continue the development of innovative system concepts (for example, packaged units) and innovative applications (such as industrial parks).

- Cultivate a resident expertise particularly through the case study program to respond to design problems in solar applications in industry.

- Implement cooperative programs with industrial users and with solar equipment suppliers to identify promising applications of solar energy.

- Support the extension of design and simulation codes and attendant cost analysis codes to enable the aforementioned work to be accomplished.

\section{SECTION 5.0}

\section{REFERENCES}

1. Brown, K. C. et al. End-Use Matching for Solar Industrial Process Heat. SERI/TR333-09 1. Golden, CO: Solar Energy Research Institute; for theoming.

2. Collares-Pereira, M.; Rabl, A. Collector Comparison Based on Yearly Average Performance. SERI/TR-34-304. Golden, CO: Solar Energy Research Institute; June 1979.

3. May, E. K. Solar Energy in the Oil Refining Industry. SERI/TR-351-562. Golden, CO: Solar Energy Research Institute; fortheoming.

4. Brown, K. C. et al. Analysis of Industries with Potential for Solar Industrial Process Heat. SERI/TR-333-468. Golden, CO: Solar Energy Research Institute; forthcoming. 
5. Hooker, D. W.; West, R. E. Industrial Process Heat Case Studies. SERI/TR-333323. Golden, CO: Solar Energy Research Institute; for thcoming.

6. Kutscher, C:; Davenport, R. Performance Results and Experience of the Operational Industrial Process Heat Field Tests. SERI/TR-333-385. Golden, CO: Solar Energy Research Institute; forthcoming.

7. Glenn, Barbara. Putting the Sun to Work in Industry. SERI/SP-34-175. Golden, CO: Solar Energy Research Institute; Feb. 1979.

8. Dickinson, W. C.; Brown, K. C. Economic Analysis of Solar Industrial Process Heat Systems. UCRL-52814. Livermore, CA: Lawrence Livermore Laboratory; 17 Aug. 1979.

9. Green, H. J. Cooperative Effort for Industrial Energy Data Collection (IEDC). SERI/RR-333-422. Golden, CO: Solar Energy Research Institute; Oct. 1979.

\section{SECTION 6.0}

\section{BIBLIOGRAPHY}

Other reports published in this program but not referenced include:

Brown, K. C. "Near-Term Prospects for Solar Industrial Process Heat." Proceedings: Sixth Energy Technology Conference, Washington, D.C.: 26-28 Feb. 1979.

Brown, K. C.; Edesess, M.; Jayadev, T. S. Solar Ponds for Industrial Process Heat. SERI/TP-351-460. Golden, CO: Solar Energy Research Institute; Oct. 1979,

Brown, K. C.; Ketels, P. A.; and Stadjuhar, S. A. Industrial Applications Analysis: Market Characterization and System Definition for Several Industries. SERI/TP-353467. Golden, CO: Solar Energy Research Institute; Nov. 1979.

Brown, K. C.; Stadjuhar, S. A. "Matching Solar Systems to Industrial Needs." ASME Paper No. 79-Sol-28, presented at the ASME Gas Turbine and Solar Energy Conference and Exhibit; San Diego, CA: 12-15 Mar. 1979.

Brown, K. C.. "Goals: Objects and Measures of Progress." SERI/TP-351. Golden, CO: Solar Energy Research Institute; Jan. 1980.

Hooker, D. W. and West, R. E. Two Case Studies of the Application of Solar Energy for Industrial Process Heat. SERI/TP-333-427. Golden, CO: Solar Energy Research Institute; Oct. 1979.

Stadjuhar, 3. A. "An Appliculions Anulysis for the Solar Industrial Process Heat Market." Proceedings: 10th Annual Pittsburgh Modeling and Simulation Conference; Pittsburgh, PA: Apr. 1979. 


\begin{tabular}{|c|c|c|}
\hline $\begin{array}{l}\text { Document Control } \\
\text { Page }\end{array}$ & \begin{tabular}{|l|l|}
$\begin{array}{l}\text { 1. SERI Report No. } \\
\text { TR-35]-481 }\end{array}$ & 2. NTIS Accession No. \\
\end{tabular} & 3. Recipient's Accession No. \\
\hline \multirow{2}{*}{\multicolumn{2}{|c|}{$\begin{array}{l}\text { 4. Title and Subtitle } \\
\text { Appiications and Systems Studies for Solar Industrial } \\
\text { Process Heat }\end{array}$}} & $\begin{array}{r}\text { 5. Publication Date } \\
\text { January } 1980\end{array}$ \\
\hline & & \multirow{2}{*}{\begin{tabular}{|l}
6. \\
8. Periorming Organization Rept. No.
\end{tabular}} \\
\hline $\begin{array}{l}\text { 7. Author(s) } \\
\text { Kenneth C. Brow }\end{array}$ & n & \\
\hline \multicolumn{2}{|c|}{$\begin{array}{l}\text { Solar Energy Research Institute } \\
\text { l617 Cole Boulevard } \\
\text { Golden, Co } 80401\end{array}$} & $\begin{array}{l}\text { 11. Contract (C) or Grant (G) No. } \\
\text { (C) } \\
\text { (G) }\end{array}$ \\
\hline \multicolumn{2}{|c|}{ 12. Sponsoring Organization Name and Address } & 13. Type of Report \& Period Covered \\
\hline \multicolumn{3}{|l|}{ 15. Supplementary Notes } \\
\hline \multicolumn{3}{|c|}{ 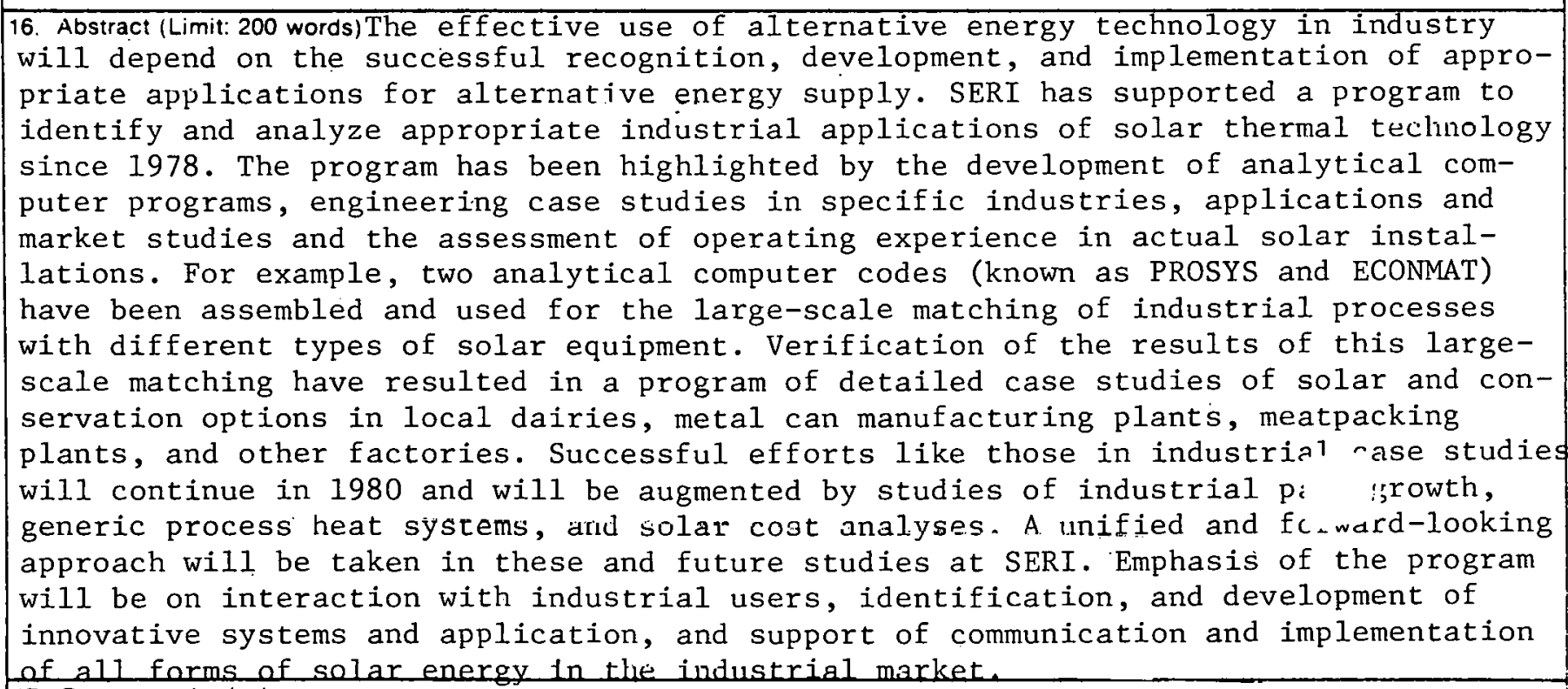 } \\
\hline \multicolumn{3}{|c|}{$\begin{array}{l}\text { 17. Document Analysis } \\
\text { a. Descriptors Industrial Process Heat; Research Programs; } \\
\text { Models; Data Analysls; Case Studice; Cost Benefit An } \\
\text { b. Identifiers/Open-Endeo Terms ECONMAT: PROSYS }\end{array}$} \\
\hline \multicolumn{3}{|l|}{ c. UC Categories } \\
\hline \multicolumn{3}{|l|}{$59 c$} \\
\hline \multirow{2}{*}{\multicolumn{2}{|c|}{$\begin{array}{l}\text { 18. Availability Statcment } \\
\text { National Technical Information Service } \\
\text { U. S. Department of Commerce. } \\
5285 \text { Port Royal Road } \\
\text { Springfield, VA } 22161\end{array}$}} & $\begin{array}{c}\text { 19. No of Pages } \\
15\end{array}$ \\
\hline & & $\begin{array}{r}20 . \text { Price } \\
\end{array} 4.00$ \\
\hline
\end{tabular}

